\title{
Agronomic performance of naked oat (Avena nuda L.) and faba bean intercropping
}

\author{
Agnieszka Klimek-Kopyra ${ }^{*}$, Bogdan Kulig ${ }^{1}$, Andrzej Oleksy ${ }^{1}$, and Tadeusz Zając ${ }^{1}$
}

The most common cereals for faba bean (Vicia faba L.) used in intercrops is conventional oat (Avena sativa L.) An alternative to oat may be naked oat (Avena nuda L.), whose oil content and quality is double. Here, intercropping of naked oat with two different faba bean cultivars (determinate-high tannin and indeterminate-low tannin) was compared with sole crops of each species in 2006-2008. The treatments were: sole naked oat at 500 kernels $\mathrm{m}^{2}$, indeterminate sole faba bean at 50 seeds $\mathrm{m}^{2}$, determinate sole faba bean at 70 seeds $\mathrm{m}^{2}$, and an additive series of $25 \%, 50 \%$, and $75 \%$ of faba bean seeding rate mixed with the naked oat seeding rate. Our results demonstrated that intercropping increased the Land Equivalent Ratio by $+3 \%$ to $+9 \%$ over sole cropping. Raising the faba bean seeding rate in a mixture from $25 \%$ to $75 \%$ reduced oat grain yield from 630 (determinate cultivar) to $760 \mathrm{~kg} \mathrm{ha}^{-1}$ (indeterminate cultivar) but increased faba bean grain yield from $760 \mathrm{~kg}^{-1}$. Higher yield and leaf area index (LAI) and photosynthetically active radiation (PAR) values show that the indeterminate cultivar of faba bean is more suitable in mixture with naked oat. The high value of competition index $(\mathrm{CR}>1)$ indicates domination and aggressiveness of faba bean towards naked oat. Regardless of cultivar type, mixture of faba bean with naked oat is less productive than pure sowing.

Key words: Competition index, Vicia faba.

\section{INTRODUCTION}

Among various grain legume crops grown in Europe, faba bean (Vicia faba L.) ranks presently second in area and production after pea (Baddeley et al., 2013). Cultivated faba bean is mainly used as human food in developing countries and as animal feed for pigs, horses, poultry, and pigeons in industrialized countries (Rubiales, 2010; Flores et al., 2012). Faba bean is a very promising crop thanks to its protein value, high stem strength compared to other legumes and its adaptation to a range of temperate growing conditions (Strydhorst et al., 2008; Jensen et al., 2010).

Faba bean is mostly grown as a sole crop but in some countries intercropping with cereals is a common practice (Agegnehu et al., 2006; Tosti and Guiducci, 2010; Dordas and Lithourgidis, 2011; Dhima et al., 2013). A wide use of faba bean intercropping is used for seed and forage production (Lithourgidis and Dordas, 2010; Dhima et al., 2013). One of the factors affecting faba bean yield and its quality in intercropping system is the selection of companion crop and the seeding ratios (Dordas and Lithourgidis, 2011). However, it is not entirely clear which

\footnotetext{
${ }^{1}$ Agriculture University in Krakow, Institute of Plant Production, Aleja Mickiewicza 21,31-120, Krakow, Poland.

*Corresponding author (klimek.a@wp.pl).

Received: 14 August 2014.

Accepted: 30 January 2015

doi:10.4067/S0718-58392015000200005
}

faba bean-cereal combinations or which seeding rates are the best for intercropping. In recent years numerous cereals-faba bean combinations were observed. The most common cereals for faba bean used in intercrops are Avena sativa L., A. byzantina K. Koch, Triticum durum Desf., Hordeum vulgare L., and studies on $\times$ Triticosecale spp. have also been reported (Agegnehu et al., 2006; Tosti and Guiducci, 2010; Dordas and Lithourgidis, 2011). Agegnehu et al. (2008) noticed that intercropping of wheat with faba bean may increase both total yield and land-use efficiency (3\%-22\%). According to the authors, increasing the faba bean seeding rate in a mixture from $12.5 \%$ to $62.5 \%$ reduced wheat grain yield but increased faba bean grain yield. Additionally, the synergistic effect of intercropping on total productivity was presented. Total yield and system productivity index of wheat-faba bean intercropping at the $100: 37.5$ seeding rate exceeded the sole yield. Nonetheless, the negative association between the yields of the two crops indicates some degree of competition for space and resources between the crops. Hence, improved productivity in one crop as a component of the system may result in yield reduction of the other component. Wheat and faba bean are usually characterized by similar growth duration, so that when grown together, both crops can utilize resources at the same time, which results in competition among the component crops. Helenius and Jokinen (1994) indicated the potential of intercropped oats and faba bean. Oats had a greater yield potential than faba bean, however, yield potential depends on seeding rates. The authors have demonstrated that 400 
kernels of oats per $\mathrm{m}^{2}$ and 40 seeds of faba beans per 1 $\mathrm{m}^{2}$ are the most suitable densities determining high seed yield. Land Equivalent Ratio (LER) of this mixture is 1.10 for seed yield, which indicated a yield advantage. Dhima et al. (2013) indicated that faba bean-oat (A. sativa subsp. byzantina (K. Koch) Romero Zarco) intercrops provided higher total DM than those of faba bean in a sole crop, but lower or similar yield to oat as a sole crop. According to Dhima et al. (2013), faba bean with oat (A. sativa subsp. byzantina) at a $25: 75$ seeding ratio could be used as an alternative to faba bean sole crop or faba bean-cereals intercrops for forage yield.

Until now there was hardly any information on other $A$. sativa subspecies yielding in crop mixtures. Naked oat $(A$. $n u d a)$ is a little known subspecies of Avena spp. cultivated mostly as fodder crop. However, there are certain issues that should be taken into consideration to ensure production of a top quality crop. Unfortunately, the effect of intercropping on the competitive relationships in crops and yielding potential of naked oat with both determinate and indeterminate faba bean cultivars is unknown. We assumed that naked oat has high yield potential, which can be demonstrated in intercropping with faba bean.

The objectives of the present study were i) to evaluate naked oat and two types of faba bean varieties (determinate-high tannin and indeterminate-low tannin) cultivated in sole cropping as well as in intercrops at three seeding ratios $(25: 75,50: 50$, and $75: 25)$ for seed yield, and ii) to estimate the effect of intercropping on the parameters of vegetation indices (leaf area index, LAI; photosynthetically active radiation, PAR), and iii) to estimate the effect of intercropping (naked oat and determinate and indeterminate faba bean cultivars) on the competitive relationships.

\section{MATERIALS AND METHODS}

The experiment was carried out on the Experimental Farm of the University of Agriculture in Kraków (50 $07^{\circ} 10^{\prime \prime}$ $\mathrm{N}, 20^{\circ} 05^{\prime} 04^{\prime \prime} \mathrm{E} ; 150 \mathrm{~m}$ a.s.l.) in southern Poland in the growing seasons of 2006-2008. The experiment was established in a Chernozem soil (Luvic Phaeozem according to WRB classification (IUSS Working Group WRB, 2014) with pH 5.7-6.6, 0.9-1.1\% organic C, $13 \mathrm{mg}$

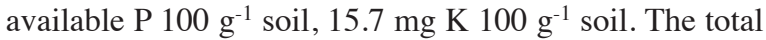
monthly rainfall and the average temperature for each growing season are shown in Figure 1. The previous crop was winter wheat. Naked oat 'Polar' (P) and two faba bean cultivars 'Olga' $(\mathrm{O}$; indeterminate-low- tannin) and 'Optimal' (OL; determinate-high tannin) were compared in a sole crop and in a mixture at three seeding ratios (25:75, 50:50, and 75:25). Six different mixtures were compared: Mixture 1 (M1) 25\% 'Olga', 75\% 'Polar'; Mixture 2 (M2) 50\% 'Olga', 50\% 'Polar'; Mixture 3 (M3) 75\% 'Olga', 25\% 'Polar'; Mixture 4 (M4) 25\% 'Optimal', 75\% 'Polar'; Mixture 5 (M5) 50\% 'Optimal',

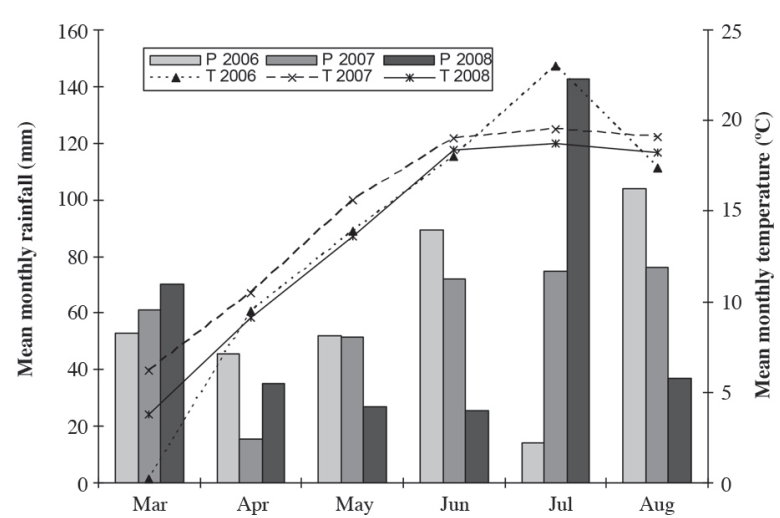

Figure 1. Monthly total rainfall and average air temperature during the three growing seasons of experimentation.

50\% 'Polar'; and Mixture 6 (M6) 75\% 'Optimal', 25\% 'Polar'. Seeds were sown during the last third of March (2006) and the second third of April (2007 and 2008). The crop was fertilized with 80 and $120 \mathrm{~kg} \mathrm{ha}^{-1}$ of $\mathrm{P}_{2} \mathrm{O}_{5}$ and $\mathrm{K}_{2} \mathrm{O}$, respectively. The experiment was established by means of a randomized complete block design with four replicates. The size of the experimental plots was $11 \mathrm{~m}^{2}$ and the size of rows for faba bean was $50 \mathrm{~cm}$, for plants in a mixture and for naked oat it was $14 \mathrm{~cm}$. Crops of mixed cultures were harvested separately for each crop from the whole plot. After threshing, seeds were cleaned, weighed, and adjusted at $12 \%$ and $10 \%$ moisture levels for oat and faba bean respectively. Before harvesting, samples of plants had been collected from $0.25 \mathrm{~m}^{2}$ of each plot to conduct biometric measurements. Yield structure components were estimated (number of plants per unit area, number of pods per plant, number of seeds per pod, and thousand grains weight). Seed moisture content was measured after harvest.

\section{Calculation of the vegetation indices of canopy, yield} and yield components

In 2006-2008 LAI and PAR were measured at the main development stages by means of SunScan Canopy Analysis System (Delta-T Devices, Cambridge, UK).

The Land Equivalent Ratio (LER) was used as an index for mixed stand advantage for both legume (faba bean) and cereal (naked oat). LER values were calculated as follows:

$$
\text { Land Equivalent Ratio }=\left(Y_{a} / Y_{A}\right)+\left(Y_{b} / Y_{B}\right)
$$

where $Y_{a}$ and $Y_{b}$ are the component yields of crops A (oat) and B (faba bean) in intercropping, and $Y_{A}$ and $Y_{B}$ are the yields of sole cultures of $\mathrm{A}$ and $\mathrm{B}$ on a similar unit area. A LER of 1.0 indicates equal advantages for intercropping and sole cropping, values more than 1.0 indicate more advantage for intercropping than for sole cropping and values less than 1.0 indicate less advantage for intercropping than for sole cropping 
(Dhima et al., 2007). The other index used to determine the competitive relationship between two crops in mixtures is aggressiveness (A) (Bhatti et al., 2006).

Aggressiveness is formulated by Federer (1993) as indicated below:

$$
\begin{gathered}
\text { Aggressiveness }=[\mathrm{Yob} /(\mathrm{YaZob})]-[\mathrm{Ybo} /(\mathrm{YbZbo})] \mathrm{Ab}= \\
{[\mathrm{Ybo} /(\mathrm{YbZbo})]-[\mathrm{Yob} /(\mathrm{YoZob})],}
\end{gathered}
$$

where, $Z b o$ and $Z o b$ are the seeding rates of faba bean and oat in a seed mixture. If Aoat $=0$ both crops are equally competitive, if Aoat is positive oat is dominant, if Aoat is negative oat is dominated by faba bean in the mixture (Wahla et al., 2009).

Competitive ratio (CR) is another way to assess competitive ability between different species (Willey and Rao, 1980). The CR gives more desirable competitive ability for the crops and also advantages over other indexes. Then, the CR index was formulated as below:

$$
\text { Competitive ratio }=(L E R b / L E R a)(Z b a / Z a b)
$$

\section{Statistical analysis}

The Statistics (version 10) software (IBM Corporation, Armonk, New York, USA) was used to conduct the ANOVA. Fisher's least significant difference test was used to identify differences between treatment means. The level of significance was verified by Tukey's test, $\mathrm{p} \leq 0.05$.

\section{RESULTS AND DISCUSSION}

The average seed yield of the morphologically varied type of faba bean varieties cultivated as a sole crop and in mixture with naked oat was $1.25 \mathrm{t}$ ha, and it ranged 0.63-1.82 $\mathrm{t} \mathrm{ha}^{-1}$. The cultivation of faba bean with naked oat positively influenced yield amount and stabilization. The mixture with a higher sharing of faba bean $(50 \%$; $75 \%$ seeding rate) achieved a significantly higher yield regardless of variety type. Additionally, a considerably higher yield, comparable to the mixture of 75 seeding ratio, was obtained by faba bean in a sole crop. Different results were gained by Dordas and Lithourgidis (2011) and Dhima et al. (2013), who compared yield of faba bean and A. sativum and A. bizantinum crop mixture. The author found that DM yield of faba bean crop in mixture was significantly higher in 25:75 seeding ratio.

The yielding of faba bean varied and was determined by weather conditions throughout vegetations seasons (Table 1). In 2007, which was a favorable season for growth and development, faba bean had the highest yield, while a substantial amount of rain in 2006 was beneficial for oat yielding. Unfavorable weather conditions during the generative plant development in 2006 and in 2008 contributed to the decrease of thousand-grain weight of faba bean, hence lower then potentially possible faba bean yielding (Table 1). A thousand grain weight ranged 315-372 $\mathrm{g}$. The number of pods per plant and the number of seeds per pod were greatly dependent on the seeding ratio and variety. The highest number of seeds per pod was showed (2.94) by the determinate variety ('Optimal') with the highest seeding ratio $(75 \%)$, while the highest average number of pods per plant was obtained by the indeterminate variety in sole cropping (8.79).

Table 2 presents the yield components of naked oat. Thousand grains weight varied in vegetation seasons. The lowest plant density and the highest thousand grain weight were observed in 2007. The opposite situation was observed in 2006 and 2008. The sharing of faba bean in mixture with naked oat did not influence the kernel

Table 2. Intercropping effect on thousand-kernel weight (TKW), kernel per panicle (KPP), kernel per panicle (KPP), stand count (SC) of naked oat.

\begin{tabular}{llccc}
\hline Treatments & $\begin{array}{l}\text { Grain } \\
\text { yield }\end{array}$ & TKW & KPP & SC \\
\hline & $\mathrm{t} \mathrm{ha}^{-1}$ & $\mathrm{~g}$ & $\mathrm{nr}$ & $\mathrm{m}^{-2}$ \\
Year & & & & \\
2006 & 1.86 & $21.7 \mathrm{~b}$ & $32.06 \mathrm{a}$ & $357.6 \mathrm{~b}$ \\
2007 & 1.60 & $27.2 \mathrm{c}$ & $40.27 \mathrm{~b}$ & $195.0 \mathrm{a}$ \\
2008 & 1.80 & $18.5 \mathrm{a}$ & $77.03 \mathrm{c}$ & $205.1 \mathrm{a}$ \\
Intercropping & & & & \\
Sole naked oat & $2.36 \mathrm{~d}$ & 22.1 & 46.3 & $378.6 \mathrm{c}$ \\
Faba bean 'Olga'/naked oat (25:75) & $2.09 \mathrm{~cd}$ & 22.7 & 48.2 & $274.0 \mathrm{~b}$ \\
Faba bean'Olga'/naked oat (50:50) & $1.80 \mathrm{bc}$ & 22.3 & 56.9 & $252.0 \mathrm{~b}$ \\
Faba bean'Olga'/naked oat (75:25) & $1.33 \mathrm{a}$ & 22.5 & 50.7 & $145.3 \mathrm{a}$ \\
Faba bean 'Optimal'/naked oat (25:75) & $1.88 \mathrm{bc}$ & 21.7 & 49.9 & $307.0 \mathrm{bc}$ \\
Faba bean 'Optimal'/naked oat (50:50) & $1.56 \mathrm{ab}$ & 22.9 & 47.6 & $257.1 \mathrm{~b}$ \\
Faba bean 'Optimal'/naked oat (75:25) & $1.25 \mathrm{a}$ & 23.1 & 48.6 & $154.0 \mathrm{a}$ \\
\hline
\end{tabular}

Letters in the row indicate significant differences according to Tukey's test

\begin{tabular}{|c|c|c|c|c|c|}
\hline Treatments & Grain yield & TSW & SPP & PPP & $\mathrm{SC}$ \\
\hline & $\mathrm{tha}^{-1}$ & g & 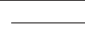 & 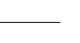 & $\mathrm{m}^{-2}$ \\
\hline \multicolumn{6}{|l|}{ Year } \\
\hline 2006 & $1.19 \mathrm{a}$ & 327.2 & $2.37 \mathrm{~b}$ & $7.86 b$ & $19.9 \mathrm{a}$ \\
\hline 2007 & $1.64 b$ & 352.3 & $1.95 \mathrm{a}$ & $8.30 \mathrm{~b}$ & $32.1 b$ \\
\hline 2008 & $1.23 \mathrm{a}$ & 333.3 & $2.47 \mathrm{~b}$ & $5.25 \mathrm{a}$ & $31.5 b$ \\
\hline \multicolumn{6}{|l|}{ Intercropping } \\
\hline Sole faba bean 'Olga' & $1.76 \mathrm{c}$ & 344.2 & $2.14 \mathrm{ab}$ & $8.79 b$ & $38.12 \mathrm{~d}$ \\
\hline Sole faba bean 'Optimal' & $1.82 \mathrm{c}$ & 315.4 & $1.82 \mathrm{a}$ & $8.20 \mathrm{ab}$ & $44.03 \mathrm{e}$ \\
\hline Faba bean 'Olga'/naked oat $(25: 75)$ & $0.63 \mathrm{a}$ & 372.7 & $2.21 \mathrm{ab}$ & $6.70 \mathrm{ab}$ & $17.79 \mathrm{a}$ \\
\hline Faba bean 'Olga'/naked oat (50:50) & $1.03 \mathrm{ab}$ & 342.4 & $2.13 \mathrm{ab}$ & $6.03 \mathrm{a}$ & $22.83 \mathrm{ab}$ \\
\hline Faba bean 'Olga'/naked oat $(75: 25)$ & $1.57 \mathrm{c}$ & 334.0 & $2.24 \mathrm{ab}$ & $6.34 \mathrm{ab}$ & $26.83 b c$ \\
\hline Faba bean 'Optimal'/naked oat (25:75) & $0.94 \mathrm{ab}$ & 327.4 & $2.94 \mathrm{~b}$ & $7.31 \mathrm{ab}$ & $17.62 \mathrm{a}$ \\
\hline Faba bean 'Optimal'/naked oat (50:50) & $1.36 \mathrm{bc}$ & 333.2 & $2.11 \mathrm{ab}$ & $6.89 \mathrm{ab}$ & $24.33 \mathrm{ab}$ \\
\hline Faba bean 'Optimal'/naked oat (75:25) & $1.70 \mathrm{c}$ & 331.5 & $2.52 \mathrm{ab}$ & $6.82 \mathrm{ab}$ & $31.25 \mathrm{c}$ \\
\hline
\end{tabular}
$(\mathrm{P} \leq 0.05)$.

Table 1. Intercropping effect on thousand-seed weight (TSW), seed per pod (SPP), pods per plant (PPP), and stand count (SC) of faba bean.

Letters in the row indicate significant differences according to Tukey's test $(\mathrm{P} \leq 0.05)$. 
number in a panicle and the thousand grain weight in any significant way. It was frequently indicated (Dordas and Lithourgidis, 2011; Dhima et al., 2013) that plant density of both oat and faba bean is crucial in yield formation. In our experiment the average plant density for faba bean was 26.2 plants $\mathrm{m}^{-2}$ and was related to the companion crops interaction. According to Willey and Rao (1980), changes in the seeding ratios of intercrop species can alter the competitive dynamics between species. Furthermore, Bhatt et al. (2010) emphasized that the proportion of different species in an intercrop can influence photosynthesis and chlorophyll content, which in turn can affect the productivity of the intercropping system.

The results of leaf area index (LAI) are presented in Figure $2 \mathrm{a}$ and $2 \mathrm{~b}$. Faba bean had better environmental conditions for growth and development and therefore gained higher LAI compared to naked oat. Depending on the time of measurements, the average LAI value in faba bean ranged 0.81 to $4.5 \mathrm{~cm}^{2} \mathrm{~cm}^{-2}$. The determinate variety had higher LAI, however, a higher value was observed in mixture. Except for the first mixture ( 25 faba bean: 75 naked oat), a low value of LAI (2.60) compared to pure sowing was observed. Our results were supported by Eskandari (2011) and López-Bellido et al. (2005), who claimed that the value of LAI is higher in a mixture characterized by higher plant density. The maximum LAI value was observed during the flowering stage, what is also supported by López-Bellido et al. (2005).
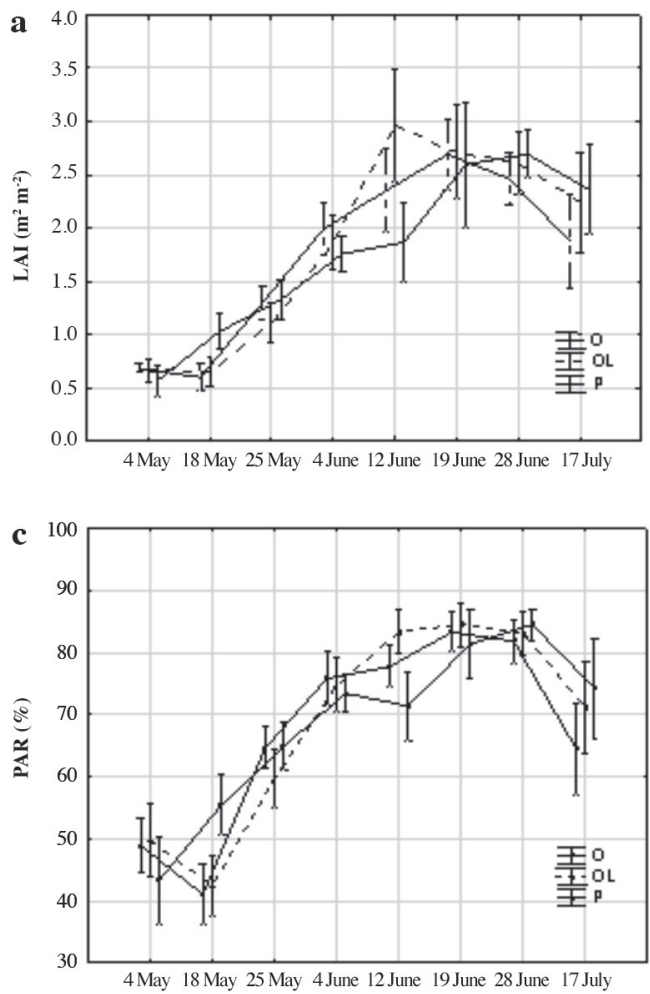

All mixtures had a higher PAR value compared to a sole crop (Figure 2c and 2d). Both types of faba bean varieties in a sole crop had a higher value of PAR only at the time of maximum leaves development, i.e. the increase of faba bean seeding ratio in a mixture contributed to the development of a bigger leaf area. The sharing of PAR absorption in a canopy ranged 38\%-95\%. The greatest advantage of PAR was noticed in the mixture M5 with 50:55 seeding ratio.

The value of PAR depends on the effective light absorption and its conversion in cropping. According to Stützel and Aufhammer (1992), very high plant densities accelerated crop closing and earlier maximization of PAR value. In our results, both plant density and variety type significantly modified the value of PAR. Despite higher density of naked oat in sole cropping, the highest PAR value was obtained by the indeterminate faba bean.

Mixture with the determinate faba bean variety with $25 \%$ seeding rate had the highest PAR. Keating and Carberry (1993) concluded that as in breeding processes plants are adapted to absorb light at a maximum level in a sole crop there is low probability that opposite results can be gained in a mixture. However, in our research a higher PAR value was obtained in a mixture with low seeding rate of faba bean. The competition ability of species in intercropping indicated crucial correlations between seeding rate of a companion crop in a mixture. The increase of faba bean seeding ratio in a mixture from
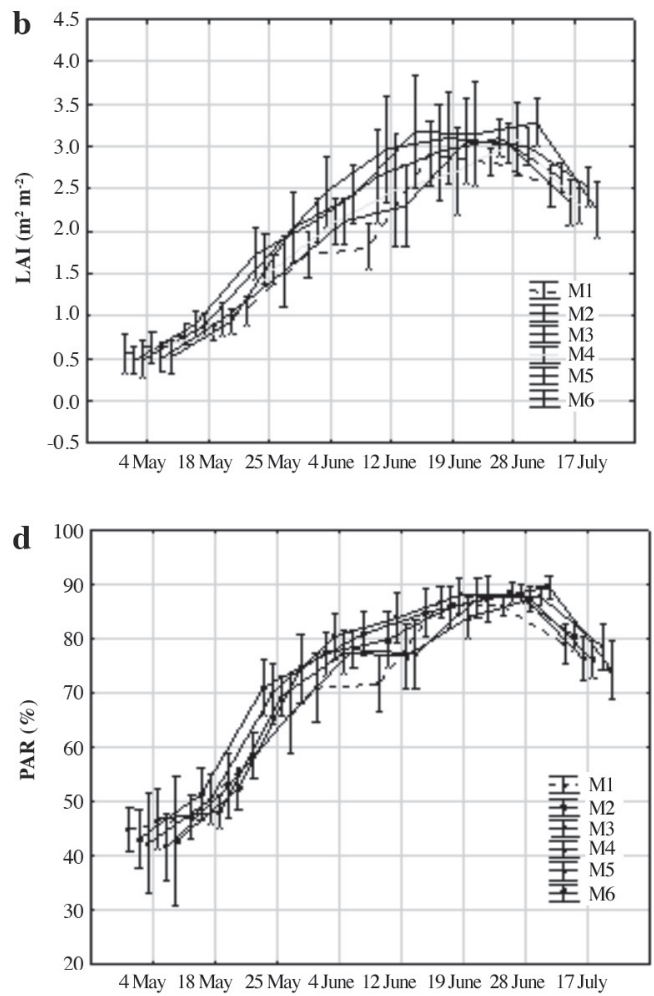

O: 'Olga', OL: 'Optimal', P: 'Polar', M1-M6: mixture combinations.

Figure 2. Leaf area index (LAI) and photosynthetically active radiation (PAR) distributions in pure sowing of faba bean or naked oat (a,c) and in mixture $(b, d)$. 
$25 \%$ to $75 \%$ raised plant competition in crop. Dhima et al. (2013) contradicted our research. According to these authors, the increase of faba bean in a mixture decreased naked oat competition. On that basis it can be assumed that plant density in intercropping can shape biomass yield and seed yield in a mixture in a different way. Additionally, light availability as an effect of plant density in crop mixture can escalate plant competition.

Faba bean turned out be a stronger competitor in intercropping than naked oat, what was observed in a higher CR index. The analysis of competition indices calculated for faba bean and naked oat in mixtures indicated variability in crop interactions during vegetation seasons (Table 3). In the compared plant mixtures the value of CRb was always higher than 1 during rainfall seasons, which indicated strong competition for water resources between crop components. In 2007, characterized by the shortage of rainfall, naked oat was more competitive than faba bean, which resulted in the lower yield of faba bean. Raising the faba bean seeding ratio up to $75 \%$ increased competition of this species regardless of faba bean type. However, by comparison of the competition between the two types of faba bean varieties it was noticed that the determinate variety was a stronger competitor. The value of CRo for naked oat significantly varied plant density in a mixture. Very low $(25 \%)$ density of naked oat in mixture with the indeterminate faba bean variety was more beneficial for oat. Our results are supported by Helenius and Jokinen (1994) and Neugschwandtner and Kaul (2014), who noticed that oats was a stronger competitor due to its greater yield potential than bean or pea. The mixture sown in densities of 400 kernels of oats per square meter and 40 seeds of faba beans per square meter was the most productive intercrop with respect to seed yield.

The competition index is closely linked to plant domination in crops. Our results showed that faba bean gained a positive value of the aggressiveness index, which indicated that faba bean established stronger domination than oats in a mixture. The value of aggressiveness index was varied in vegetation seasons. The highest faba bean aggressiveness was obtained during heavy rainfall conditions (2008). The weakest domination of faba bean in a mixture was observed during the shortage of rainfall (2006). The highest density of the determinate faba bean (75\%) was the least advantageous.

The analysis of plant interaction indicated that in all compared mixtures a partial complementary use of limited growth factors (e.g. nutrients, water, light) was noticed because the increase of the yield of a dominating species did not influence the decrease of the yield of the dominated species. The highest value of LER, above 1, was gained in a mixture of $75 \%$ seeding ratio with the indeterminate faba bean. It was frequently indicated (Dhima et al., 2007; Wahla et al., 2009; Pasynkova and Zavalin, 2010) that cereals dominated in a crop mixture, except for wheat. Our results contradicted the above mentioned and established that naked oat was dominated by faba bean regardless of the seeding ratio. It was often concluded that disadvantages depend mainly on companion crops, mixture ratios, and experimental years (Lithourgidis et al., 2006).

\section{CONCLUSION}

The cultivation of faba bean in two different formations (determinate and indeterminate varieties) with naked oat was beneficial to the latter. The sharing of the lowest (25\%) seeding ratio of the indeterminate faba bean caused an increase of naked oat yielding. The highest (75\%) seeding ratio of the determinate faba bean variety with naked oat caused an increase of faba bean yield.

The values of leaf area index (LAI) and photosynthetically active radiation (PAR) indicated plant competition in a mixture. The highest value of LAI and PAR was observed in mixtures, which was not reflected in yield.

Naked oat was a greater competitor during the shortage of rainfall, while faba bean in heavy rainfall conditions. The determinate faba bean cultivar in a higher seeding ratio (up to $75 \%$ ), gained the strongest domination in mixture.

Table 3. The effect of intercropping on component grain yield, competitive ratio (CR), land equivalent ratio (LER), aggressiveness (A) of faba bean and naked oat.

\begin{tabular}{|c|c|c|c|c|c|c|}
\hline \multirow[b]{2}{*}{ Treatments } & \multicolumn{3}{|c|}{ Faba bean } & \multicolumn{3}{|c|}{ Naked oat } \\
\hline & $\mathrm{CR}$ & LER & A & $\mathrm{CR}$ & LER & A \\
\hline \multicolumn{7}{|l|}{$\overline{\text { Year }}$} \\
\hline 2006 & $1.13 \mathrm{a}$ & $0.77 \mathrm{a}$ & $1.06 \mathrm{a}$ & $1.32 \mathrm{a}$ & 0.72 & -1.06 \\
\hline 2007 & $0.85 \mathrm{a}$ & $0.48 \mathrm{a}$ & $0.36 \mathrm{a}$ & $2.21 \mathrm{~b}$ & 0.72 & -0.36 \\
\hline 2008 & $2.51 \mathrm{~b}$ & $1.44 \mathrm{~b}$ & $2.40 \mathrm{~b}$ & $0.90 \mathrm{a}$ & 0.66 & -2.40 \\
\hline \multicolumn{7}{|l|}{ Intercropping } \\
\hline Faba bean 'Olga'/naked oat $(25: 75)$ & $0.49 \mathrm{a}$ & $0.41 \mathrm{a}$ & 0.91 & $2.75 \mathrm{c}$ & $0.89 \mathrm{c}$ & -0.91 \\
\hline Faba bean 'Olga'/naked oat (50:50) & $1.00 \mathrm{a}$ & $0.73 \mathrm{ab}$ & 1.33 & $1.36 \mathrm{ab}$ & $0.77 \mathrm{bc}$ & -1.33 \\
\hline Faba bean 'Olga'/naked oat $(75: 25)$ & $2.03 \mathrm{~b}$ & $1.19 \mathrm{~b}$ & 1.31 & $0.61 \mathrm{a}$ & $0.56 \mathrm{a}$ & -1.31 \\
\hline Faba bean 'Optimal'/naked oat $(25: 75)$ & $0.74 \mathrm{a}$ & $0.56 \mathrm{ab}$ & 1.10 & $2.02 \mathrm{bc}$ & $0.79 b c$ & -1.10 \\
\hline Faba bean 'Optimal'/naked oat (50:50) & $1.94 \mathrm{~b}$ & $1.22 \mathrm{~b}$ & 1.42 & $1.49 \mathrm{ab}$ & $0.67 \mathrm{ab}$ & -1.42 \\
\hline Faba bean 'Optimal'/naked oat (75:25) & $2.80 \mathrm{~b}$ & $1.28 \mathrm{~b}$ & 1.53 & $0.66 \mathrm{a}$ & $0.54 \mathrm{a}$ & -1.53 \\
\hline
\end{tabular}

Letters in the row indicate significant differences according to Tukey's test $(\mathrm{P} \leq 0.05)$. 


\section{LITERATURE CITED}

Agegnehu, G., A. Ghizaw, and W. Sinebo. 2006. Yield performance and land-use efficiency of barley and faba bean mixed cropping in Ethiopian high lands. European Journal of Agronomy 25:202-207. doi:10.1016/j.eja.2006.05.002.

Agegnehu, G., A. Ghizaw, and W. Sinebo. 2008. Yield potential and land-use efficiency of wheat and faba bean mixed intercropping. Agronomy for Sustainable Development 28:257-263. http:// dx.doi.org/10.1051/agro:200801.

Baddeley, J.A., S. Jones, C.F.E. Topp, C.A. Watson, J. Helming, and F.L. Stoddard. 2013. Biological nitrogen fixation (BNF) by legume crops in Europe. Legume Futures Report 1.5. Available at http:// www.legumefutures.de/images/Legume_Futures_Report_1.5.pdf (accessed June 2014).

Bhatt, M.V.,A. Khandelwal, and S.A. Dudley. 2010. Kin recognition, not competitive interactions, predicts root allocation in young Cakile edentula seedling pairs. New Phytologist 189:1135-1142. doi:10.1111/j.1469-8137.2010.03548.x.

Bhatti, I.H., R. Ahmad, A. Jabbar, M.S. Nazir, and T. Mahmood. 2006. Competitive behaviour of component crops in different sesame - legume intercropping systems. International Journal of Agriculture and Biology 8:165-167. doi:1560-8530/2006/08-2$165-167$.

Dhima, K.V., A.S. Lithourgidis, I.B. Vasilakoglou, and C.A. Dordas. 2007. Competition indices of common vetch and cereal intercrops in two seeding ratio. Field Crops Research 100:249256. doi:10.1016/j.fcr.2006.07.008.

Dhima, K.V., I.B. Vasilakoglou, R.Xh. Keco, A.K. Dima, K.A. Paschalidis, and T.D. Gatsis. 2013. Forage yield and competition indices of faba bean intercropped with oat. Grass and Forage Science 69:376-383. doi:10.1111/gfs.12084.

Dordas, C.A., and A.S. Lithourgidis. 2011. Growth, yield and nitrogen performance of faba bean intercrops with oat and triticale at varying seeding ration. Grass and Forage Science 66:569-577.

Eskandari, H. 2011. Intercropping of wheat (Triticum aestivum) and bean (Vicia faba): Effects of complementarity and competition of intercrop components in resource consumption on dry matter production and weed growth. African Journal of Biotechnology 10:17755-17762. doi:10.5897/AJB11.2250.

Federer, W.T. 1993. Some analytical variations for intercropping studies. p. 225-241. In Federer, W.T. (ed.) Statistical design and analysis for intercropping experiments. Springer, New York, USA. doi:10.1007/978-0-387-22647-7_8.

Flores, F., S. Nadal, I. Solis, J. Winkler, O. Saa, F.L. Stoddard, et al. 2012. Faba bean adaptation to autumn sowing under European climates. Agronomy for Sustainable Development 32:727-734. doi:10.1007/s13593-012-0082-0.

Helenius, J., and K. Jokinen. 1994. Yield advantage and competition in intercropped oats (Avena sativa L.) and faba bean (Vicia faba L.): Application of the hyperbolic yield-density model. Field Crops Research 37:85-94. doi:10.1016/0378-4290(94)90036-1.
IUSS Working Group WRB. 2014. World reference base for naming soils and creating legends for soil maps. Word Soil Resources Reports Nr 106. FAO, Rome, Italy.

Jensen, E.S., M.B. Peoples, and N.H. Nielsen. 2010. Faba bean in cropping systems. Field Crops Research 115:203-216. doi:10.1016/j.fcr.2009.10.008.

Keating, B.A., and P.S. Carberry. 1993. Resource capture and use in intercropping: solar radiation. Field Crops Research 34:273-301. doi:10.1016/0378-4290(93)90120-C.

López-Bellido, F.J., L. López-Bellido, and R.J. López-Bellido. 2005. Competition, growth and yield of faba bean (Vicia faba L.) European Journal of Agronomy 23:359-378. doi:10.1016/j. eja.2005.02.002.

Lithourgidis, A.S., and C.A. Dordas. 2010. Forage yield, growth rate, and nitrogen uptake of faba bean intercrops with wheat, barley, and rye in three seeding ratios. Crop Science 5:2148-2158. doi: 10.2135/cropsci2009.12.0735.

Lithourgidis, A.S., I.B. Vasilakoglou, K.V. Dhima, C.A. Dordas, and M.D. Yiakoulaki. 2006. Forage yield and quality of common vetch mixtures with oat and triticale in two seeding ratios. Field Crops Research 99:106-113. doi:10.1016/j.fcr.2006.03.008.

Neugschwandtner, R.W., and H.-P. Kaul. 2014. Sowing ratio and $\mathrm{N}$ fertilization affect yield and yield components of oat and pea in intercrops. Field Crops Research 155:159-163. doi:10.1016/j. fcr.2013.09.010

Pasynkova, E.N., and A.A. Zavalin. 2010. Evaluation of the efficiency of spring wheat and vetch mixed crops. Russian Agricultural Sciences 36:5-8. doi:10.3103/S1068367410010027.

Rubiales, D. 2010. Faba beans in sustainable agriculture. Field Crop Research 115:201-202. doi:10.1016/j.fcr.2009.11.002.

Strydhorst, S.M., J.R. King, K.J. Lopetinsky, and K.N. Harker. 2008. Weed interference, pulse species, and plant density effects on rotational benefits. Weed Science 56:249-258. doi:10.1614/WS07-118.1.

Stützel, H., and W. Aufhammer. 1992. Grain yield in determinate and indeterminate cultivars of Vicia faba with different plant distribution patterns and population densities. The Journal Agricultural Science 118:343-352. doi:10.1017/ S0021859600070714.

Tosti, G., and M. Guiducci. 2010. Durum wheat-faba bean temporary inter-cropping: Effects on nitrogen supply and wheat quality. European Journal of Agronomy 33:157-165. doi:10.1016/j. eja.2010.05.001.

Wahla, I.H., R. Ahmad, Ehsanullah, A. Ahmad, and A. Jabbar. 2009. Competitive functions of components crops in some barley based intercropping systems. International Journal of Agriculture and Biology 11:69-72. doi:08-050/AKA/2009/11-1-69-72.

Willey, R.W., and M.R. Rao. 1980. A competitive ratio for quantifying competition between intercrops. Experimental Agriculture 16:117-125. 